\title{
Pengaruh Pemanfaatan Sistem Informasi Akuntansi Keuangan Daerah, Kapasitas Sumber Daya Manusia dan Pengendalian Internal Terhadap Kualitas Laporan Keuangan Pemerintahan Daerah Kabupaten Sikka Emilianus Eo Kutu Goo ${ }^{a^{*}}$, Paulus Libu Lamawitak ${ }^{\mathrm{b}}$ \\ ${ }^{a, b}$ Universitas Nusa Nipa \\ $a^{*}$ Email: emilyogowi2013@gmail.com
}

\begin{abstract}
ABSTRAK
Penelitian ini bertujuan untuk meneliti pengaruh pemanfaatan sistem informasi akuntansi keuangan daerah, kapasitas sumber daya manusia dan pengendalian internal terhadap kualitas laporan keuangan Pemerintah Daerah Kabupaten Sikka. Sumber data dalam penelitian ini adalah data primer dengan teknik pengumpulan data menggunakan kuisioner yang disebarkan kepada responden sebanyak 33 Pegawai pada Badan Pengelola Keuangan Dan Asset Daerah (BPKAD) Kabupaten Sikka. Metode analisis data yang digunakan dalam penelitian ini adalah analisis regresi. Hasil penelitian menunjukkan bahwa pemanfaatan sistem informasi akuntansi keuangan daerah tidak berpengaruh terhadap kualitas laporan keuangan pemerintah daerah sedangkan kapasitas sumber daya manusia dan sistem pengendalian internal berpengaruh terhadap kualitas laporan keuangan pemerintah daerah Kabupaten Sikka.
\end{abstract}

Kata kunci: Pemanfaatan Sistem Informasi Akuntansi Keuangan Daerah, Kapasitas Sumber Daya Manusia, Sistem Pengendalian Intern, Kualitas Laporan Keuangan Pemerintah Daerah.

\section{ABSTRACT}

This study aims to examine the effect of utilization of regional financial accounting information systems, human resource capacity and internal control on the quality of financial reports of the Regional Government of Sikka Regency. Sources of data in this study are primary data with data collection techniques using questionnaires distributed to respondents as many as 33 employees at the Regional Financial and Asset Management Agency (BPKAD) Sikka Regency. The data analysis method used in this research is Regression Analysis. The results showed that the use of regional financial accounting information systems had no effect on the quality of local government financial reports, while the human resource capacity and internal control systems had an effect on the quality of local government financial reports in Sikka Regency.

Keywords: Utilization of Regional Financial Accounting Information Systems, Human Resource Capacity, Internal Control Systems, and Quality of Local Government Financial Reports

\section{PENDAHULUAN}

Perkembangan sektor publik di Indonesia yang kian pesat telah memberikan dampak terhadap lembaga-lembaga pemerintah dimana lembaga-lembaga pemerintah dituntut lebih akuntabilitas. Menurut Mardiasmo (2009:178), akuntabilitas merupakan keharusan suatu instansi pemerintahan organisasi untuk mempertanggungjwabkan segala kegiatan organisasinya kepada publik. Salah satu bentuk pertanggungjawaban publik yang diatur dalam Undang-Undang Nomor 17 Tahun 2003 tentang Keuangan Negara dan Undang-Undang Nomor 23 Tahun 2014 tentang Pemerintah Daerah adalah pemerintah daerah berkewajiban menyusun laporan keuangan secara periodik.

Sistem Informasi Akuntansi pemerintah daerah mengacu pada Peraturan Pemerintah Nomor 56 tahun 2005 yang telah direvisi dengan Peraturan Pemerintah Nomor 65 tahun 2010 yang mewajibkan setiap pemerintah daerah menerapkan Sistem Informasi Keuangan Daerah dalam mengelola keuangan daerah. Pemanfaatan sistem informasi akuntansi keuangan daerah 
sangat dibutuhkan dalam menciptakan laporan keuangan yang berkualitas. Pemanfaatan sistem informasi akuntansi keuangan daerah dalam pengelola keuangan daerah dilakukan dengan memanfaatkan program informasi teknologi untuk mendukung sistem informasi keuangan daerah.

Kualitas laporan keuangan adalah penyajian laporan keuangan yang memiliki kriteria antara lain: (a) kesesuaian dengan SAP, (b) kecukupan pengungkapan, (c) kepatuhan terhadap peratuan perundang-undangan, (d) efektivitas sistem pengendalian intern. Kualitas laporan keuangan berpengaruh pada akuntabilitas, dengan kualitas laporan keuangan yang baik akan memberikan pertanggungjawaban atas laporan keuangan yang dibuat, hal tersebut akan berpengaruh terhadap pemberian opini atas kewajaran informasi keuangan yang disajikan (Tuasikal, $2007: 43$ ).

Laporan keuangan yang baik tidak dapat dipisahkan dari faktor kapasitas sumber daya manusia. Kapasitas sumber daya manusia merupakan kemampuan yang dimiliki seseorang dalam suatu organisasi untuk melaksanakan fungsi-fungsi atau kewenangannya untuk mencapai tujuannya secara efektif dan efisien. Oleh karena itu, kapasitas sumber daya manusia memiliki pengaruh terhadap kualitas laporan keuangan.

Untuk menghasilkan informasi keuangan yang bermanfaat bagi para pemakai, maka laporan keuangan harus disusun oleh personel yang memiliki kapasitas dibidang pengelola keuangan daerah dan sistem akuntansi. Menurut Tuasikal (2007 : 39) menyatakan bahwa peningkatan kapasitas sumber daya manusia dipengaruhi oleh peran aparatur yang mendorong pegawai/staf memanfaatkan teknologi informasi agar tujuan pengelolaam keuangan tercapai.

Adanya dukungan sistem pengendalian intern yang kuat tentunya akan meningkatkan kualitas laporan keuangan pemerintah daerah. Berdasarkan UU No. 15 Tahun 2004 tentang Pemeriksaan Pengelolaan dan Tanggung Jawab Keuangan Negara, penilaian kewajaran informasi keuangan dalam laporan keuangan berdasarkan pada kriteria efektivitas SPI. Badan Pemeriksa Keuangan (BPK) selaku auditor eksternal senantiasa menguji "kekuatan" SPI ini di setiap pemeriksaan yang dilakukannya untuk menentukan luas lingkup pengujian yang akan dilaksanakannya.

Fenomena buruknya kualitas informasi laporan keuangan daerah memberikan peluang bagi adanya penyimpangan dan kekeliruan di bidang keuangan, terlihat dari banyaknya pejabat yang terjerat kasus hukum dan dapat menimbulkan kerugian negara/daerah. Dalam kenyataannya, Badan Pemeriksa Keuangan (BPK) masih menemukan banyak permasalahan pada pengelolaan keuangan pemerintahan daerah Kabupaten Sikka saat melakukan pemeriksaan atau audit atas Laporan Keuangan Pemerintah Daerah (LKPD) yang menunjukkan lemahnya akuntabilitas Pengelola keuangan daerah.

Dari hasil audit Badan Pemeriksa Keuangan (BPK) atas LKPD Kabupaten Sikka selama lima tahun, dari tahun 2015-2019, BPK memberikan opini WDP (Wajar Dengan Pengecualian) dan WTP (Wajar Tanpa Pengecualian), sebagaimana tersaji dalam tabel 1. 
Tabel 1. Opini Badan Pemeriksa Keuangan (BPK) untuk Kabupaten Sikka Tahun 2015-2019

\begin{tabular}{|c|c|c|}
\hline Tahun & Opini BPK & Keterangan \\
\hline 2015 & $\begin{array}{l}\text { Wajar Dengan } \\
\text { Pengecualian }\end{array}$ & $\begin{array}{l}\text { Aset Tetap, diantaranya inventarisasi atas asset } \\
\text { tetap pada Dinas Pendidikan Pemuda dan } \\
\text { Olahraga (PPO) belum selesai dilaksanakan. } \\
\text { Penerimaan dan Pengeluaran dari Bantuan } \\
\text { Operasional Sekolah (BOS) belum disajikan dan } \\
\text { diungkapkan dalam laporan keuangan. }\end{array}$ \\
\hline 2016 & $\begin{array}{l}\text { Wajar Tanpa } \\
\text { Pengecualian }\end{array}$ & $\begin{array}{l}\text { Temuan SPI, Penatausahaan dan Pengelola Kas } \\
\text { belum memadai dan Pengelola piutang PBB pada } \\
\text { Badan Pendapatan Daerah dan piutang retribusi } \\
\text { pelayanan pasar pada Dinas Perdagangan, } \\
\text { Koperasi dan UKM belum memadai. }\end{array}$ \\
\hline 2017 & $\begin{array}{l}\text { Wajar Tanpa } \\
\text { Pengecualian }\end{array}$ & $\begin{array}{l}\text { Temuan Kepatuhan, pemutusan kontrak } \\
\text { pembangunan gedung Kantor Bupati pada Dinas } \\
\text { PUPR belum dilakukan pemeriksaan fisik atas } \\
\text { hasil akhir pekerjaan dan pencairan jaminan } \\
\text { pelaksanaan serta penagihan denda } \\
\text { keterlambatan. Terdapat kekurangan volume } \\
\text { pekerjaan terpasang sebesar } 1.21 \text { Miliar dan } \\
\text { denda keterlambatan belum ditetapkan pada } \\
\text { pekerjaan pembangunan gedung Poliklinik } \\
\text { RSUD dr. T.C. Hillers. }\end{array}$ \\
\hline 2018 & $\begin{array}{l}\text { Wajar Tanpa } \\
\text { Pengecualian }\end{array}$ & $\begin{array}{l}\text { BPK menemukan permasalahan yakni } \\
\text { Penatausahaan dan Pengelola Kas yang belum } \\
\text { tertib. Terdapat kelebihan pembayaran pekerjaan } \\
\text { lanjutan pembangunan gedung Kantor Bupati } \\
\text { tahap II, pemeliharaan berkala jalan Kewapante- } \\
\text { sp. Habibola. selain itu juga terdapat kelebihan } \\
\text { pembayaran pembangunan Puskesmas } \\
\text { Wolomarang dan pekerjaan perluasan jaringan } \\
\text { IKK Talibura serta kelebihan pembayaran gaji } \\
\text { dan tunjangan kepada pegawai yang sudah tidak } \\
\text { aktif. }\end{array}$ \\
\hline 2019 & $\begin{array}{l}\text { Wajar Tanpa } \\
\text { Pengecualian }\end{array}$ & - \\
\hline
\end{tabular}

Sumber : http://kupang.tribunnews.com

Dalam Laporan Keuangan Pemerintah Daerah Kabupaten Sikka ternyata masih adanya sistem pengendalian interen yang lemah, hal ini dinyatakan dalam opini BPK meskipun 
pemerintah kabupaten berhasil menjadikan laporan keuangan mendapat opini WTP dari BPK. Masih adanya ketidakpatuhan terhadap peraturan perundang - undangan dalam Pengelola keuangan daerah.

Akan menjadi tantangan tersendiri bagi pemerintah daerah dalam mewujudkan akuntabilitas keuangan yang berkualitas yang tercermin melalui opini auditor. Pentingnya upaya dan komitmen dari berbagai pihak dan aspek yang menentukan kualitas informasi dari laporan keuangan pemerintah daerah sehingga akan menghasilkan opini Wajar Tanpa Pengecualian dari tim audit BPK. Pemerintah daerah yang seharusnya mendapatkan opini Wajar Tanpa Pengecualian harus dapat mengoptimalkan pemanfaatan APBD setempat (Tuasikal, 2007 : 37).

Hipotesis yang diajukan dalam penelitian ini dapat dirumuskan sebagai berikut:

H1 : Pemanfaatan Sistem Informasi Akuntansi Keuangan Daerah Berpengaruh Terhadap Kualitas Laporan Keuangan Pemerintah Deerah.

H2 : Kapasitas sumber daya manusia berpengaruh terhadap kualitas laporan keuangan pemerintah daerah.

H3 : Sistem pengendalian intern berpengaruh terhadap kualitas laporan keuangan pemerintah daerah

\section{METODE PENELITIAN}

Jenis penelitian ini menggunakan metode eksplanatory research, yaitu metode yang menjelaskan secara sistematis faktual dan akurat mengenai suatu objek yang diteliti dan bertujuan untuk mencari ada tidaknya pola hubungan dan sifat hubungan dua variabel atau lebih serta menguji hipotesis bahkan menemukan teori baru (Nazir, 1998:16). Penelitian ini dilakukan untuk melihat pengaruh pemanfaatan sistem informasi akuntansi keuangan daerah, kapasitas Sumber Daya Manusia dan sistem pengendalian intern terhadap kualitas laporan keuangan Pemerintah Daerah Kabupaten Sikka.

Populasi dalam penelitian ini merupakan seluruh pegawai pada kantor Badan Pengelola Keuangan dan Aset Daerah (BPKAD) Kabupaten Sikka yang berjumlah 33 orang. Teknik pengambilan sampel dalam penelitian ini yaitu nonprobability sampling dengan teknik samplingnya yaitu sampling jenuh dimana semua anggota populasi dijadikan sebagai sampel (Sugiyono,2011:68), sehingga diperoleh anggota sampel sebanyak 33 orang.

Teknik analisis data dalam penelitian ini dibagi ke dalam enam tahap yaitu analisis deskripsi; pengujian kualitas data berupa uji validitas dan uji reliabilitas; uji asumsi klasik yaitu uji normalitas,uji multikolonearitas dan uji heteroskedastisitas; analisis regresi berganda; uji ketepatan model yaitu uji keofisien determinasi dan uji $\mathrm{F}$;, dan uji hipotesis yaitu uji t.

\section{HASIL DAN PEMBAHASAN}

\section{Deskripsi Responden}

Data yang digunakan dalam penelitian ini adalah data primer, yaitu data yang diperoleh secara langsung dari obyek penelitian. Dalam penelitian ini, menggunakan kuesioner yang dibagikan kepada 33 responden pegawai yang ada di kantor Badan Pengelola Keuangan dan Aset Daerah (BPKAD) Kabupaten Sikka yang bertindak sebagai sampel. Kuesioner yang dibagikan terdiri dari 4 variabel yaitu pemanfaatan sistem informasi akuntansi keuangan 
daerah, kapasitas sumber daya manusia, pengendalian internal dan kualitas laporan keuangan pemerintahan daerah.

Berdasarkan hasil kuisioner yang dibagikan kepada responden diketahui :

1. Responden dengan jenis kelamin laki-laki sebanyak 18 responden $(54.5 \%)$ dan perempuan sebanyak 15 responden $(45,5 \%)$.

2. Usia responden adalah yang berkisar dari umur 41-50 tahun yaitu sebanyak 20 orang $(60,6 \%)$ selanjutnya disusul dengan usia 31-40 tahun sebanyak 10 orang $(30,3 \%)$, usia responden $>50$ tahun sebanyak 2 orang $(6.1 \%)$ dan kemudian usia 20-30 tahun sebanyak 1 orang $(3.0 \%)$.

3. Jabatan responden terbanyak yaitu Pegawai/Staf sebanyak 19 orang $(57,5 \%)$, selanjutnya Kepala Sub Bagian sebanyak 10 orang $(30,3 \%)$ kemudian posisi bendahara 2 orang $(6,1 \%)$ dan sekretaris 2 orang $(6,1 \%)$.

4. Tingkat pendidikan responden yang paling banyak adalah tamatan SMA yaitu sebanyak 14 orang $(42.4 \%)$ disusul tamatan S1 sebanyak 12 orang (36.4\%) dan yang terakhir adalah tamatan D3 sebanyak 7 orang (21.2\%). Latar belakang jurusan responden yaitu pendidikan lain-lain sebanyak 15 orang $(45.5 \%)$, akuntasi sebanyak 13 orang $(39,4 \%)$, sosial dan manejemen sebanyak 5 orang $(15.1 \%)$.

5. Lama bekerja responden dalam menduduki jabatan struktural yang berkaitan dengan penyusunan pelaporan keuangan dan sebagai kepala subbagian keuangan/akuntansi di dinas atau badan tempat dia bekerja paling lama yaitu 1-5 tahun sebanyak 20 responden $(60.6 \%)$. yang menjabat $>5$ tahun sebanyak $9(27.3 \%)$ dan $<1$ tahun sebanyak 4 responden $(12,1 \%)$.

\section{Deskripsi Variabel Penelitian}

Dalam penelitian ini terdiri dari 3 variabel bebas yaitu pemanfaatan sistem informasi akuntansi keuangan daerah (X1), kapasitas sumber daya manusia (X2) dan pengendalian internal (X3) serta 1 satu variabel terikat yaitu kualitas laporan keuangan pemerintahan daerah (Y) Kabupaten Sikka. Berikut ini adalah tabel dan deskripsi tentang tanggapan dari 33 responden pegawai yang ada di kantor Badan Pengelola Keuangan dan Aset Daerah (BPKAD) Kabupaten Sikka. Perhitungan data dari setiap variabelnya diolah dengan menggunakan aplikasi statistik yaitu program IBM SPSS Statistics 26.

\section{Pemanfaatan Sistem Informasi Akuntansi Keuangan Daerah}

Berdasarkan hasil olah data menggunakan aplikasi statistik yaitu program IBM SPSS Statistics 26 diketahui bahwa dari 33 responden, sebagian besar responden yaitu sebanyak 83 jawaban atau 50,30\% menyatakan setuju terhadap item atau pernyataan dari variabel pemanfaatan sistem informasi akuntansi keuangan daerah. Terdapat 82 jawaban atau 49,70\% menyatakan sangat setuju terhadap item atau pernyataan dari variabel pemanfaatan sistem informasi akuntansi keuangan daerah.

\section{Kapasitas Sumber Daya Manusia}

Berdasarkan hasil olah data menggunakan aplikasi statistik yaitu program IBM SPSS Statistics 26 diketahui bahwa dari 33 responden, sebagian besar responden yaitu sebanyak 91 
jawaban atau 55,15\% menyatakan setuju terhadap item atau pernyataan dari variabel kapasitas sumber daya manusia. Terdapat 69 jawaban atau 41,82\% menyatakan sangat setuju, dan sebanyak 5 jawaban atau 3,03\% menyatakan netral terhadap item atau pernyataan dari variabel kapasitas sumber daya manusia.

\section{Sistem Pengendalian Intern}

Berdasarkan hasil olah data menggunakan aplikasi statistik yaitu program IBM SPSS Statistics 26 diketahui bahwa dari 33 responden, sebagian besar responden yaitu sebanyak 170 jawaban atau $73,59 \%$ menyatakan setuju terhadap item atau pernyataan dari variabel sistem pengendalian intern. Terdapat 58 jawaban atau 25,11\% menyatakan sangat setuju, sebanyak 2 jawaban atau 0,87\% menyatakan netral, dan 1 jawaban atau 0,43\% menyatakan tidak setuju terhadap item atau pernyataan dari variabel sistem pengendalian intern.

\section{Kualitas Laporan Keuangan Pemerintah Daerah}

Berdasarkan hasil olah data menggunakan aplikasi statistik yaitu program IBM SPSS Statistics 26 diketahui bahwa dari 33 responden, sebagian besar responden yaitu sebanyak 217 jawaban atau 73,31\% menyatakan setuju terhadap item atau pernyataan dari variabel kualitas laporan keuangan pemerintah daerah. Terdapat 74 jawaban atau 25\% menyatakan sangat setuju, dan sebanyak 5 jawaban atau 1,69\% menyatakan netral terhadap item atau pernyataan dari variabel kualitas laporan keuangan pemerintah daerah.

\section{Analisis Data}

\section{Uji validitas dan Reliabilitas}

Uji validitas

Uji Validitas digunakan untuk mengukur sah atau tidaknya suatu kuesioner. Suatu kuesioner dikatakan valid atau sahih jika pertanyaan pada kuesioner mampu mengungkapkan sesuatu yang akan diukur oleh kuesioner tersebut. Suatu kuesioner dikatakan valid jika nilai korelasi ( $r$ hitung) lebih besar $r$ tabel (Ghozali,2011 : 243). Suatu instrumen dikatakan valid apabila taraf probabilitas kesalahan (sig) lebih kecil dari 0,05 dan $r$ hitung lebih besar dari $r$ tabel, sebaliknya suatu instrumen dikatakan tidak valid apabila taraf probabilitas kesalahan (sig) lebih besar 0,05 dan $r$ itung lebih kecil dari $r$ tabel (Ghozali, 2011 : 274).

Nilai $r$ hitung dicari menggunakan program IBM SPSS Statistics 26, sedangkan $r$ tabel dicari pada tabel $\mathrm{r}$ dengan melihat degree of freedom ( $\mathrm{df}$ ) yaitu banyaknya sampel $(\mathrm{n})=33$ dan alpha =0,05, (Sugiyono,2011:45) sehingga diperoleh nilai $r$ hitung sebesar 0,333. 
Tabel 2. Hasil Uji Validitas

\begin{tabular}{|c|c|c|c|}
\hline Variabel & $\begin{array}{l}\text { Nomor } \\
\text { Item }\end{array}$ & $\begin{array}{c}\text { Corrected Item- } \\
\text { Total } \\
\text { Correlation }\end{array}$ & Keterangan \\
\hline Pemanfaatan Sistem & $\mathrm{X}_{1.1}$ & 0,805 & Valid \\
\hline Informasi Akuntansi & $\mathrm{X}_{1.2}$ & 0,717 & Valid \\
\hline \multirow[t]{3}{*}{ Keuangan Daerah (X1) } & $X_{1.3}$ & 0,617 & Valid \\
\hline & $\mathrm{X}_{1.4}$ & 0,824 & Valid \\
\hline & $\mathrm{X}_{1.5}$ & 0,748 & Valid \\
\hline \multirow{5}{*}{$\begin{array}{l}\text { Kapasitas Sumber Daya } \\
\text { Manusia (X2) }\end{array}$} & $\mathrm{X}_{2.1}$ & 0,887 & Valid \\
\hline & $\mathrm{X}_{2.2}$ & 0,860 & Valid \\
\hline & $\mathrm{X}_{2.3}$ & 0,898 & Valid \\
\hline & $\mathrm{X}_{2.4}$ & 0,877 & Valid \\
\hline & $\mathrm{X}_{2.5}$ & 0,848 & Valid \\
\hline \multirow{8}{*}{$\begin{array}{l}\text { Sistem Pengendalian Intern } \\
\text { (X3) }\end{array}$} & $\mathrm{X}_{3.1}$ & 0,765 & Valid \\
\hline & $X_{3.2}$ & 0,530 & Valid \\
\hline & $\mathrm{X}_{3.3}$ & 0,834 & Valid \\
\hline & $X_{3.4}$ & 0,777 & Valid \\
\hline & $X_{3.5}$ & 0,740 & Valid \\
\hline & $X_{3} .6$ & 0,643 & Valid \\
\hline & $X_{3.7}$ & 0,713 & Valid \\
\hline & $\mathrm{X}_{3.8}$ & 0,793 & Valid \\
\hline \multirow{9}{*}{$\begin{array}{l}\text { Kualitas Laporan Keuangan } \\
\text { Pemerintah Derah (Y) }\end{array}$} & Y.1 & 0,708 & Valid \\
\hline & Y.2 & 0,849 & Valid \\
\hline & Y.3 & 0,696 & Valid \\
\hline & Y.4 & 0,816 & Valid \\
\hline & Y.5 & 0,908 & Valid \\
\hline & Y.6 & 0,862 & Valid \\
\hline & Y.7 & 0,559 & Valid \\
\hline & Y.8 & 0,694 & Valid \\
\hline & Y.9 & 0,760 & Valid \\
\hline
\end{tabular}

\section{Sumber : Data Olahan}

Berdasarkan tabel hasil uji validitas di atas diketahui bahwa seluruh item pertanyaan kuesioner yang terbagi dari 4 bagian dan terdiri dari 37 pertanyaan, mempunyai nilai $r$ hitung lebih besar daripada $\mathrm{r}$ tabel dan sesuai dengan dasar pengambilan keputusan tersebut maka seluruh item pertanyaan kuesioner dapat dinyatakan valid.

\section{Uji Reliabilitas}

Uji reliabilitas merupakan alat untuk mengukur suatu kuesioner yang merupakan indikator dari variabel atau konstruk. Suatu kuesioner dikatakan reliabel atau handal jika jawaban seseorang terhadap pertanyaan adalah konsisten atau stabil. Suatu kuesioner dikatakan reliabel atau handal jika nilai Alpha Cronbach's lebih besar dari 60\%, (Ghozali, 2011 : 265).

Metode pengambilan keputusan pada uji reliabilitas menggunakan batasan $60 \%$ atau 0,6 dengan kriteria sebagai berikut: 
1) Nilai Alpha Cronbach's 0,00 s.d. 0,20 berarti kurang reliabel.

2) Nilai Alpha Cronbach's 0,21 s.d. 0,40 berarti agak reliabel.

3) Nilai Alpha Cronbach's 0,42 s.d. 0,60 berarti cukup reliabel.

4) Nilai Alpha Cronbach's 0,61 s.d. 0,80 berarti reliabel.

5) Nilai Alpha Cronbach's 0,81 s.d. 1,00 berarti sangat reliabel.

Rangkuman hasil uji reliabel untuk masing-masing variabel menggunakan program IBM SPSS Statistics 26 dapat dilihat pada tabel 3

Tabel 3.Ringkasan hasil uji reliabilitas

\begin{tabular}{llccc}
\hline \multirow{2}{*}{ No } & \multicolumn{2}{c}{ Variabel } & $\begin{array}{c}\text { Cronbach } \\
\text { Alpha }\end{array}$ & Keterangan \\
\hline 1 & $\begin{array}{l}\text { Pemanfaatan Sistem Informasi } \\
\text { Akuntansi Keuangan Daerah }\end{array}$ & 0,796 & Reliabel \\
\hline 2 & \multicolumn{2}{l}{ Kapasitas Sumber Daya Manusia } & 0,922 & Sangat Reliabel \\
\hline 3 & Sistem Pengendalian Internal & 0,868 & Sangat Reliabel \\
\hline 4 & $\begin{array}{l}\text { Kualitas Laporan Keuangan } \\
\text { Pemerintah Derah }\end{array}$ & 0,902 & Sangat Reliabel \\
\hline
\end{tabular}

Sumber : Data Olahan

Berdasarkan tabel ringkasan hasil ujian reliabilitas di atas, diketahui angka Cronbach Alpha untuk masing-masing variabel lebih besar dari nilai minimal Cronbach Alpha 0,60. Oleh karena itu dapat disimpulkan bahwa instrumen penelitian yang digunakan untuk mengukur keempat variabel dalam penelitian dapat dikatakan reliabel atau handal.

\section{Uji Asumsi Klasik}

\section{Uji Normalitas}

Berdasarkan hasil uji normalitas menggunakan program IBM SPSS Statistics 26, diketahui besarnya nilai Kolmogorov-Smirnov adalah 3,168 dan signifikan pada 0,079 atau nilai Asymp. Sig. (2-tailed) lebih besar dari taraf signifikansi 0,05. Jika nilai signifikansi dari nilai Kolmogorof-Smirnov lebih besar dari 0,05, data residual yang digunakan berdistribusi normal (Ghozali, 2011:114). Kesimpulan dari uji normalitas dalam penelitian ini adalah bahwa data berdistribusi normal.

\section{Uji Multikolinearitas}

Berdasarkan hasil uji multikolinearitas menggunakan program IBM SPSS Statistics 26, diketahui bahwa nilai tolerance Pemanfaatan Sistem Informasi Akuntansi Keuangan Daerah adalah 0,866, Kapasaitas Sumber Daya Manusia adalah 0,988 dan Sistem Pengendalian Internal adalah 0,986. Ketiga nilai tolerance untuk masing-masing variabel pada model regresi ini lebih dari 0,10 . Sementara itu pada model regresi juga memiliki nilai VIF kurang dari 10. Sehingga dapat ditarik kesimpulan bahwa model regresi penelitian ini tidak terjadi multikolinearitas. 


\section{Uji Heterokedastisitas}

Berdasarkan hasil uji heterokedastisitas menggunakan program IBM SPSS Statistics 26, diketahui bahwa titik-titik yang terbentuk pada grafik scaterplot tidak membentuk pola yang jelas serta tersebar di atas dan di bawah angka 0 pada sumbu Y. Dengan demikian dapat disimpulkan bahwa model regresi yang digunakan bebas heterokedastisitas atau dengan kata lain berkondisi homokedastisitas.

\section{Analisis Regresi Linear Berganda}

Hasil pengujian asumsi klasik menyimpulkan bahwa model regresi dalam penelitian dapat digunakan. Persamaan regresi linear berganda adalah sebagai berikut:

$$
\mathrm{y}=a+b^{1} X 1+b^{2} X 2+b^{3} X 3+e
$$

Dimana:

$\begin{array}{ll}\mathrm{Y} & : \text { Kualitas Laporan Keuangan Daerah (KLKD) } \\ \mathrm{a} & : \text { Konstanta } \\ \mathrm{b}^{1}, \mathrm{~b}^{2}, \mathrm{~b}^{3} & : \text { Koefisien parameter dari masing-masing variabel } \\ \mathrm{X} 1 & : \text { Pemanfaatan SIA Keuangan Daerah (PSIAKD) } \\ \mathrm{X} 2 & : \text { Kapasitas Sumber Daya Manusia (KSDM) } \\ \mathrm{X} 3 & : \text { Sistem Pengendalian Internal (SPI) } \\ \mathrm{e} & : \text { Error }\end{array}$

Hasil analisis regresi linear berganda menggunakan aplikasi pengolahan data yaitu IBM SPSS Statistics 26 , dapat dilihat pada tabel 4 di bawah ini :

Tabel 4.Hasil Analisis Regresi Linear Berganda

\begin{tabular}{lc}
\multicolumn{1}{c}{ Variabel } & $\begin{array}{c}\text { Unstandardize } \\
\text { d Coefficients }\end{array}$ \\
\cline { 2 - 3 } (Constant $)$ & .401 \\
\hline Pemanfaatan SIA Keuangan Daerah & .039 \\
\hline Kapasitas Sumber Daya Manusia & .314 \\
\hline Sistem Pengendalian Intern & .882 \\
\hline
\end{tabular}

\section{Sumber : Data Olahan}

Dari tabel 4 di atas dapat diketahui bahwa model regresi linear berganda ditunjukkan oleh persamaan :

$\mathrm{KLKD}=0,401+0,039$ PSIAKD $+0,314 \mathrm{KSDM}+0,882 \mathrm{SPI}$

Dari persamaan regresi di atas, dapat dijelaskan bahwa :

a. Konstanta (a)

Koefisien konstanta berdasarkan hasil regresi adalah sebesar 0,401, artinya apabila variabel independen dalam penelitian ini dianggap konstan, maka kualitas laporan keuangan daerah bernilai adalah 0,401.

b. Koefisien regresi pemanfaatan SIA keuangan daerah (b1)

Koefisien regresi pemanfaatan SIA keuangan daerah berdasarkan hasil regresi adalah sebesar 0,039. Artinya apabila pemanfaatan SIA keuangan daerah mengalami kenaikan 
sebesar $1 \%$ sedangkan variabel independen lainnya dianggap konstan, maka kualitas laporan keuangan daerah akan meningkat sebesar $0,039 \%$.

c. Koefisien regresi kapasitas SDM (b2)

Koefisien regresi kapasitas SDM berdasarkan hasil regresi adalah sebesar 0,314. Artinya apabila kapasitas SDM mengalami kenaikan sebesar 1\% sedangkan variabel independen lainnya dianggap konstan, maka kualitas laporan keuangan daerah akan meningkat sebesar $0,314 \%$.

d. Koefisien regresi sistem pengendalian internal (b3)

Koefisien regresi sistem pengendalian internal berdasarkan hasil regresi adalah sebesar 0,882. Artinya apabila sistem pengendalian internal mengalami kenaikan sebesar $1 \%$ sedangkan variabel independen lainnya dianggap konstan, maka kualitas laporan keuangan daerah akan meningkat sebesar $0,882 \%$.

\section{Uji Kelayakan Model}

\section{Uji Simultan (uji F)}

Hasil uji F yang dilakukan menggunakan aplikasi pengolahan data yaitu IBM SPSS Statistics 26 , dapat dilihat pada tabel 5 di bawah ini :

Tabel 5. Hasil Uji Simultan

ANOVA $^{\mathrm{a}}$

\begin{tabular}{lrrrrr}
\hline Model & Sum of Squares & df & Mean Square & F & Sig. \\
\hline Regression & 242.952 & 3 & 80.984 & 35.705 & $.000^{\text {b }}$ \\
\hline Residual & 65.775 & 29 & 2.268 & & \\
\hline Total & 308.727 & 32 & & & \\
\hline
\end{tabular}

Sumber : Data Olahan

Berdasarkan tabel Uji Anova atau F test di atas menghasilkan F hitung sebesar 35,705 dengan tingkat signifikansi 0,000. Nilai signifikansi ini lebih kecil dari 0,05. Karena probabilitas signifikan jauh lebih kecil dari 0,05, maka model regresi dapat digunakan untuk memprediksi kualitas laporan keuangan daerah atau dapat dikatakan bahwa Pemanfaatan Sistem Informasi Akuntansi Keuangan Daerah, Kapasitas Sumber Daya Manusia, dan Sistem Pengendalian Internal secara bersama-sama berpengaruh terhadap Kualitas Laporan Keuangan Daerah.

\section{Uji Koefisien determinasi $\left(\mathbf{R}^{2}\right)$}

Hasil uji koefisien determinasi yang dilakukan menggunakan aplikasi pengolahan data yaitu IBM SPSS Statistics 26, secara lengkap dapat dilihat pada tabel 6 
Tabel 6. Hasil Uji Koefisien Determinasi

Model Summary ${ }^{b}$

\begin{tabular}{lrrr}
\hline $\mathrm{R}$ & $\mathrm{R}$ Square & Adjusted R Square & Std. Error of the Estimate \\
\hline $.887^{\mathrm{a}}$ & .787 & .765 & 1.506 \\
\hline \multicolumn{2}{c}{ Sumber : Data Olahan }
\end{tabular}

Berdasarkan tabel 6 di atas, nilai Adjusted $R^{2}$ sebesar 0,765. Artinya sebesar 76,5\% variansi variabel Kualitas Laporan Keuangan Daerah dapat dijelaskan oleh variabel Pemanfaatan Sistem Informasi Akuntansi Keuangan Daerah, Kapasitas Sumber Daya Manusia, dan Sistem Pengendalian Internal, sisanya sebesar 23,5\% dijelaskan oleh variabel lain diluar model ini.

\section{Uji Hipotesis}

Hasil uji parsial (t) yang dilakukan menggunakan aplikasi pengolahan data yaitu IBM SPSS Statistics 26, secara lengkap dapat dilihat pada tabel 7.

Tabel 7. Hasil Uji Parsial

\begin{tabular}{lrc}
\hline \multicolumn{1}{c}{ Variabel } & $\mathrm{t}$ & \multicolumn{1}{c}{ Sig. } \\
\hline & .095 & .925 \\
\hline (Constant) & .256 & .800 \\
\hline Pemanfaatan Sistem Informasi Akuntansi Keuangan Daerah & 2.497 & .018 \\
\hline Sistem Pengendalian Intern & 8.098 & .000 \\
\hline
\end{tabular}

Sumber : Data Olahan

Dari tabel 7 hasil uji parsial, dapat dijabarkan sebagai berikut :

1. Variabel pemanfaatan sistem informasi akuntansi keuangan daerah memiliki nilai signifikansi sebesar 0,80, sehingga nilai signifikansi > 0,05. Dengan demikian dapat disimpulkan bahwa variabel pemanfaatan sistem informasi akuntansi keuangan daerah tidak berpengaruh terhadap kualitas laporan keuangan daerah.

2. Variabel kapasitas sumber daya manusia memiliki nilai signifikansi sebesar 0,018 , sehingga nilai signifikansi $<0,05$. Dengan demikian dapat disimpulkan bahwa variabel kapasitas sumber daya manusia berpengaruh terhadap kualitas laporan keuangan daerah.

3. Variabel sistem pengendalian internal memiliki nilai signifikansi sebesar 0,000 , sehingga nilai signifikansi $<0,05$. Dengan demikian dapat disimpulkan bahwa variabel sistem pengendalian internal berpengaruh terhadap kualitas laporan keuangan daerah.

\section{PEMBAHASAN}

\section{Pengaruh Pemanfaatan Sistem Informasi Akuntansi Keuangan Daerah Terhadap Kualitas Laporan Keuangan Pemerintah Daerah}

Hasil penelitian menunjukan bahwa pemanfaatan sistem informasi akuntansi keuangan daerah Pemerintah Daerah Kabupaten Sikka tidak berpengaruh terhadap kualitas laporan keuangan. Hasil penelitian ini sejalan dengan hasil penelitian Diani (2014) bahwa pemanfaatan sistem informasi akuntansi keuangan daerah tidak berpengaruh signfikan 
terhadap kualitas laporan keuangan. Ini artinya bahwa sistem informasi akuntansi keuangan daerah sebagai suatu sistem informasi belum dapat membantu dalam penyajian dan peningkatan kualitas laporan keuangan pemerintah daerah itu sendiri. Salah satu penyebabnya adalah bahwa para pegawai belum memahami dengan baik tentang sistem informasi akuntansi keuangan daerah. Ini dikarenakan penempatan sebagian pegawai/staf di Pemda Kabupaten Sikka tidak sesuai dengan bidang atau displin ilmu Akuntansi sehingga pemahaman terhadap Sistem Informasi Akuntansi masih belum memadai.

Pemanfaatan sistem informasi akuntansi yang baik oleh pemerintah daerah pastinya dapat menghasilkan laporan keuangan yang berkualitas. Teknologi informasi dapat dimanfaatkan secara efektif jika pegawai/staf dalam lembaga-lembaga pemerintah dapat menggunakan teknologi tersebut dengan baik. Oleh karena itu para pegawai/staf pada pemerintah daerah Kabupaten Sikka dituntut untuk mengerti dan kegunaan sistem tersebut. Semakin baik pemanfaatan sistem informasi akuntansi keuangan daerah maka kualitas laporan keuangan yang dihasilkan akan semakin meningkat.

\section{Pengaruh Kapasitas Sumber Daya Manusia Terhadap Kualitas Laporan Keuangan Pemerintah Daerah.}

Hasil penelitian menunjukan bahwa kapasitas sumber daya manusia berpengaruh terhadap kualitas laporan keuangan Pemda Kabupaten Sikka. Hasil penelitian ini mendukung hasil penelitian Magfiroh (2015) yang menyatakan bahwa kapasitas sumber daya manusia berpengaruh terhadap kualitas laporan keuangan. Kapasitas sumber daya manusia sangat berperan penting dalam proses penyusunan laporan keuangan pemerintah daerah agar hasil laporan keuangannya menjadi berkualitas. Sumber daya manusia yang berkaitan langsung dengan sistem akan dituntut untuk memiliki keahlian akuntansi yang cukup memadai atau paling tidak memiliki kemauan untuk terus belajar danmenambah keahlian dibidang akuntansi. Apabila sumber daya manusia yang melaksanakan sistem akuntansi tidak memiliki keahlian dibidangnya, maka akan menimbulkan hambatan dalam proses pelaksanan fungsi akuntansi.

Kegagalan yang dialami oleh sumber daya manusia dalam memahami serta menerapkan ilmu akuntansi akan memiliki dampak pada laporan keuangan, seperti adanya kekeliruan laporan yang dibuat dengan standar yang telah ditetapkan pemerintah, sehingga kualitasnya menjadi buruk. Hal ini menunjukkan bahwa kapasitas sumber daya manusia yang baik, akan meningkatkan kualitas laporan keuangan pemerintah yang dihasilkan.

\section{Pengaruh Sistem Pengendalian Internal Terhadap Kualitas Laporan Keuangan Pemerintah Daerah}

Hasil penelitian menunjukan bahwa kapasitas sumber daya manusia berpengaruh terhadap kualitas laporan keuangan Pemda Kabupaten Sikka. Hasil penelitian ini sejalan dengan penelitian Susilawati (2014) bahwa sistem pengendalian intern berpengaruh signifikan terhadap kualitas laporan keuangan pemerintah daerah. Untuk menghasilkan laporan keuangan pemerintah daerah yang berkualitas diperlukan proses dan tahap-tahap yang harus dilalui yang diatur dalam sistem akuntansi pemerintah daerah. Sistem akuntansi di dalamnya mengatur tentang Sistem Pengendalian Intern (SPI), artinya bahwa kualitas laporan 
keuangan sangat dipengaruhi oleh bagus tidaknya sistem pengendalian intern yang dimiliki pemerintah daerah. Sistem pengendalian intern merupakan mekanisme kontrol dalam proses pengelolaan keuangan, sehingga kualitas laporan keuangan yang diamanatkan dalam berbagai aturan pemerintah dapat tercapai.

\section{KESIMPULAN, KETERBATASAN DAN SARAN}

Dari hasil analisis dan pembahasan maka dapat ditarik kesimpulan bahwa Kapasitas sumber daya manusia dan sistem pengendalian internal berpengaruh terhadap kualitas laporan keuangan pemerintah daerah Kabupaten Sikka, namun Pemanfaatan sistem informasi akuntansi keuangan daerah tidak berpengaruh terhadap kualitas laporan keuangan pemerintah daerah Kabupaten Sikka.

Penelitian ini masih memeiliki beberapa keterbatasan, terutama variabel yang digunakan masih terbatas dan kurang mendalam, sehingga bagi peneliti selanjutnya diharapkan menambah variabel penelitian, agar dapat diketahui adanya variabel lain yang mempengaruhi kualitas laporan keuangan pemerintah daerah.

\section{DAFTAR PUSTAKA}

Arikunto, S. (2013). Prosedur Penelitian: Suatu Pendekatan Praktik. Jakarta: Rineka Cipta. Bastian, I. (2010). Akuntansi Sektor Publik Suatu Pengantar. Jakarta : Erlangga

Diani. (2014). Pengaruh Pemahaman Akuntansi, Pemanfaatan Sistem Informasi Akuntansi Keuangan Daerah dan Peran Internal Audit Terhadap Kualitas Laporan Keuangan Pemerintahan Daerah Studi Empiris Pada SKPD Di Kota Medan. Jurnal Akuntansi, Vol. 2, No. 1 .

Ghozali, Imam. (2011). Aplikasi Analisis Multivariate dengan Program SPSS. Semarang: Badan Penerbit Universitas Diponegoro.

Magfiroh, A. (2015). Pengaruh Pengendalian Intern dan Sumber Daya Manusia Bidang Akuntansi Terhadap Kualitas Laporan Keuangan Daerah (Studi pada SKPD di Kabupaten Tebo). Jom FEKON. Vol. 2 No. 2.

Mardiasmo. (2009). Akuntansi sektor publik. Yogyakarta : Penerbit Andi.

Sugiyono. (2011). Metode Penelitian Pendidikan Pendekatan Kuantitatif, Kualitatif, dan R\&D. Bandung : Alfabeta 